\title{
Immature Aedes mosquitoes colonize Culex quinquefasciatus breeding sites in neighborhoods in the municipality of Olinda, State of Pernambuco
}

\author{
Suzane Alves dos Santos ${ }^{[1]}$ and Rosângela Maria Rodrigues Barbosa ${ }^{[1]}$
}

[1]. Departamento de Entomologia, Centro de Pesquisas Aggeu Magalhães, Fundação Oswaldo Cruz, Recife, PE.

\begin{abstract}
Introduction: The present study shows the colonization of Aedes mosquitoes in breeding sites specific for Culex quinquefasciatus in neighborhoods in the municipality of Olinda. Methods: Samples were collected between May 2011 and June 2012 from breeding sites positive for $C x$. quinquefasciatus by using a ladle and manual suction pump. Results: Aedes aegypti $(0.12 \%)$, Aedes albopictus ( $0.03 \%)$, and Cx. quinquefasciatus $(99.8 \%)$ were found across the breeding sites. Conclusions: The presence of Aedes ssp. in several $C x$. quinquefasciatus breeding sites with a heavy load of organic material demonstrates the need to review the concepts and methods used for treatment, as the use of specific larvicide for breeding sites of Culex.
\end{abstract}

Keywords: Aedes aegypti. Colonization. Breeding.

The control of urban mosquito populations, especially those of Aedes aegypti Linnaeus (1762), Aedes albopictus Skuse (1894), and Culex quinquefasciatus Say (1823) (Diptera: Culicidae), is necessary because of the involvement of these species in the transmission of human pathogens such as dengue, yellow fever, chikungunya, the Zika virus, filariasis, West Nile virus, and encephalitis, which cause discomfort to human beings and impact quality of life ${ }^{1,2}$.

The selection of breeding sites for egg-laying may be associated with factors present in the water, such as organic material, chemical compounds, and the presence of immature, among others ${ }^{3}$. Under present conditions, the abundance of egglaying sites for mosquitoes in cities complicates the monitoring of these insects and makes proper inspection impossible, frustrating efforts to reduce population densities, especially in the case of Aedes ssp.

Given the importance of developing new strategies for combating mosquito vectors, the present study aimed to identify the colonization of Ae. aegypti in breeding sites positive for $C x$. quinquefasciatus in neighborhoods with high and low infestation in the municipality of Olinda, which forms part of the Metropolitan Region of Recife, in the Brazilian State of Pernambuco.

\footnotetext{
Address to: Dra. Rosângela Maria Rodrigues Barbosa. Depto. Entomologia/ CPqAM/FIOCRUZ. Av. Morais Rego s/n, Campus da UFPE, 50670-420 Recife, PE, Brasil.

Phone: 5581 2101-2550; Fax: 5581 2101-2516

e-mail: barbosar@cpqam.fiocruz.br

Received 16 May 2014

Accepted 1 October 2014
}

Samples were collected between May 2011 and June 2012. The Municipality of Olinda is located at latitude $8^{\circ} 0^{\prime} 48^{\prime \prime} \mathrm{S}$ and longitude $34^{\circ} 50^{\prime} 42^{\prime \prime} \mathrm{W}, 6 \mathrm{~km}$ Northeast of Recife, the capital of Pernambuco. The municipality has an area of $41,681 \mathrm{~km}^{2}$ and an estimated population of 377,779 inhabitants ${ }^{4}$. This region is divided into 33 neighborhoods, grouped into two Sanitary Districts (I and II). The study investigated $C x$. quinquefasciatus breeding sites located in the neighborhoods of Sanitary District I (Caixa d'Água, Passarinho, Águas Compridas, Aguazinha, Peixinhos, Alto da Conquista, Alto do Sol Nascente, Alto da Bondade, Sapucaia, São Benedito, Vila Popular, Jardim Brasil, Salgadinho, and Sitio Novo), and strata with high and low infestation with Ae. aegypti were selected using the Rapid Aedes aegypti Survey Index [LIRAa/2011- Olinda Environmental Surveillance Center - Centro de Vigilância Ambiental de Olinda (CEVAO)].

All Culex quinquefasciatus breeding sites identified during the study possessed water with organic matter (decomposing plant and animal debris) content and little to no movement. These environmental conditions are conducive to the development of the immature stages of the species ${ }^{5}$. The breeding sites were identified and registered according to location and structural conditions. The density of larvae and pupae (DLP) was estimated using five samples from each site, four in the corners and one in the center, for restricted environments such as tanks. In larger environments, such as ditches and canals, samples were collected only from the edges, with a sample taken every $3 \mathrm{~m}$ on alternate sides when the site length was between 20 and $50 \mathrm{~m}$ and every $5 \mathrm{~m}$ when the site length was over $50 \mathrm{~m}^{6}$. Samples were initially collected using a ladle, but this apparatus was replaced in the course of the study by a manual suction pump, which could more easily obtain the immature specimens at the bottoms of the breeding sites. 
All collected samples were placed in plastic containers $(250 \mathrm{ml})$ and taken to the Entomology Laboratory of the Olinda Center for Environmental Surveillance for counting and species identification. In the laboratory, the collected larvae and pupae were placed in test tubes in $70^{\circ} \mathrm{GL}$ ethanol for identification. The culicids were identified according to external morphological characteristics on a slide under a stereoscopic microscope, using dichotomous keys described in the literature ${ }^{7}$. The numbers of immature individuals at each breeding site were compared using simple analysis of variance (ANOVA). The analyses were made in Statistica 7.0 (StatSoft) at a significance level of 5\%.

A total of 11,006 immature culicid specimens were collected, of which $9,129(82.9 \%)$ larvae and 1,861 (16.9\%) pupae were of Cx. quinquefasciatus, $12(0.11 \%)$ larvae and $1(0.01 \%)$ pupa were of Ae. aegypti, and $3(0.03 \%)$ larvae were of Ae. albopictus (Table 1).

All breeding sites were positive for $C x$. quinquefasciatus, including waterholes, canals, channels, drains, junction boxes, inspection tanks, water tanks, and ditches. The numbers of immature $C x$. quinquefasciatus found in these different types of breeding site did not differ $(\mathrm{p}>0.05)$. Four sites tested positive for Aedes ssp.: a waterhole, junction box, inspection tank, and ditch (Table 1). The numbers of immature Ae. aegypti $[\mathrm{F}(7,93)=3.1570]$ and Ae. albopictus $[\mathrm{F}(7,93)=3.1570]$ were both significantly different $(\mathrm{p}<0.05)$ in the different breeding sites. Table 2 shows that of the 14 neighborhoods inspected, only 4 contained breeding sites that tested positive for Aedes ssp. (Caixa d'Água, Passarinho, Peixinhos, and Vila Popular).

Culex quinquefasciatus, the predominant species found among the breeding sites, prefers to lay its eggs in sites with heavy loads of organic matter, and its genetic and ecological adaptations ensure its greater survival in anthropogenic environments ${ }^{8}$.
Aedes aegypti, described as a wild species that originated in Africa, has undergone changes and adaptations in egglaying behavior over time, as it has accompanied the constant global evolution of human habitation ${ }^{1}$. Aedes albopictus is a wild species that originated in Asia, has adapted to the urban environment, and is currently found in many different artificial and natural receptacles 9 . Inadequate disposal of receptacles capable of retaining water has facilitated the development of mosquito groups with the genetic flexibility to develop in these artificial habitats ${ }^{8}$.

Aedes aegypti is capable of laying groups of eggs in any receptacle in which water can accumulate ${ }^{10}$. Other biological features of this species, such as its high fertility and fecundity rate, short life cycle, capacity to adapt to environmental changes, and the resistance of its eggs to water, have also contributed to its rapid population growth ${ }^{11}$.

The artificial breeding sites for Ae. aegypti and Ae. albopictus previously described in the literature have included discarded containers, such as cans, bottles, and plastic packaging, and water reservoirs. Natural breeding sites include tree trunks ${ }^{12}$ and bodies of water rich in organic material, mainly vegetation ${ }^{13}$.

Although junction boxes, inspection tanks, and ditches are not common egg-laying or breeding sites for Ae. aegypti, all these habitats tested positive for the species in the present study, as did waterholes for Ae. albopictus. These breeding sites are typically dark locations, with little ventilation and a high concentration of volatile organic matter, making them appropriate spots for this opportunistic species to produce offspring. As further proof of the flexibility of the species, Barrera and colleagues ${ }^{14}$ found Ae. aegypti larvae in septic tanks in Puerto Rico.

During sample collection in the neighborhoods, it was observed that most areas lacked basic sanitation, contributing

TABLE 1 - Total number of larvae and pupae collected from different breeding sites in the 14 neighborhoods of Sanitary District I, Olinda, State of Pernambuco, 2012.

\begin{tabular}{|c|c|c|c|c|c|c|}
\hline \multirow{3}{*}{ Type of breeding site } & \multicolumn{6}{|c|}{ Species } \\
\hline & \multicolumn{2}{|c|}{ Aedes aegypti } & \multicolumn{2}{|c|}{ Aedes albopictus } & \multicolumn{2}{|c|}{ Culex quinquefasciatus } \\
\hline & larvae & pupae & larvae & larvae & pupae & larvae \\
\hline Waterhole & 0 & 1 & 3 & 0 & 57 & 25 \\
\hline Canal & 0 & 0 & 0 & 0 & 329 & 48 \\
\hline Junction box & 4 & 0 & 0 & 0 & 673 & 176 \\
\hline Inspection tank & 1 & 0 & 0 & 0 & 29 & 3 \\
\hline Tank & 0 & 0 & 0 & 0 & 561 & 29 \\
\hline
\end{tabular}


TABLE 2 - Total number of Aedes ssp. larvae and pupae collected at different breeding sites located in the neighborhoods of Peixinhos, Passarinho, Caixa d'Água, and Vila Popular, Olinda, State of Pernambuco, 2012.

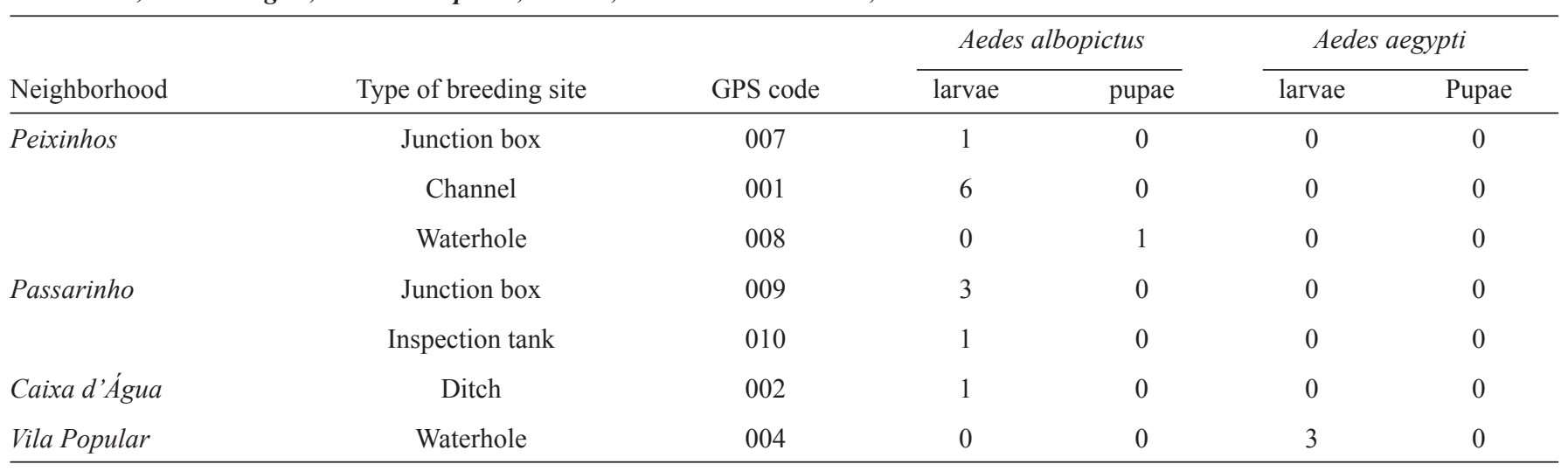

GPS: Global Positioning System.

to the large number of breeding sites testing positive for $C x$. quinquefasciatus, and that socioeconomic conditions were poor, providing potential breeding grounds for Ae. aegypti and leading to a high risk of dengue fever. Ferreira and Neto ${ }^{15}$ corroborated the findings of the present study, arguing that factors such as basic sanitation and the cultural and socioeconomic features of communities influence mosquito density and that knowledge of such factors is indispensable for better controlling vectors and reducing the number of dengue fever outbreaks.

Thus, the presence of immature Ae. aegypti and Ae. albopictus in Cx. quinquefasciatus breeding sites demonstrates the need to review the concepts and methods used for treatment of specific larvicide for breeding sites of Culex, which may have been rendered obsolete by changes in the behavior of these vectors. The introduction of new measures for monitoring and controlling vectors is thus necessary to ensure the efficiency of the entomological surveillance system.

\section{ACKNOWLEDGMENTS}

The authors wish to thank the Olinda Environmental Surveillance Center (CEVAO) for laboratory infrastructure; the vector control manager, and Dra. Eloína Santos for the statistical analysis.

\section{CONFLICT OF INTEREST}

The authors declare that there is no conflict of interest.

\section{REFERENCES}

1. Powell JR, Tabachnick WJ. History of domestication and spread of Aedes aegypti - A Review. Mem Inst Oswaldo Cruz 2013; 108:11-17.

2. Zinser M, Ramberg F, Willott E. Culex quinquefasciatus (Diptera: Culicidae) as a potential West Nile virus vector in Tucson, Arizona: blood meal analysis indicates feeding on both humans and birds. J Insect Sci 2004; 4:3.
3. Barbosa RMR, Regis L, Vasconcelos RL, Leal WS. Culex mosquitoes (Diptera: Culicidae) egg laying in traps loaded with Bacillus thuringiensis variety israelensis and baited with skatole. J Med Entomol 2010; 47:345-348.

4. Instituto Brasileiro de Geografia e Estatística (IBGE). População e domicílios. Censo 2010. [Cited July 10 2010] Available at: www.ibge.gov.br/.

5. Ministério da Saúde. Secretaria de Vigilância em Saúde, Departamento de Vigilância Epidemiológica. Guia de vigilância do Culex quinquefasciatus, Coordenação: Francisco Anilton Alves Araújo, Marcelo Santalucia, 3ª ed. Brasília: MS; 2011.

6. Fundação Nacional de Saúde (FUNASA). Controle de Vetores. Procedimentos de Segurança. Brasília: FUNASA; 2001.

7. Forattini OP. Culicidologia Médica: Identificação, Biologia, Epidemiologia. Vol. II, São Paulo: Editora da Universidade de São Paulo; 2002.

8. Lopes J. Mosquito (Diptera: Culicidae) ecology of natural and artificial rural breeding places in northern Parana, Brazil. V. Larvae captured in artificial reservoirs installed in ciliary forest. Rev Saude Publica 1997; 31:370-377.

9. Forattini OP, Marques GRAM, Kakitani I, Brito M, Sallum MAM. Significado epidemiológico dos criadouros de Aedes albopictus em bromélias. Rev Saude Publica 1998; 32:186-188.

10. Regis L, Silva SB, Melo-Santos MAV. Developing new approaches for detecting and preventing Aedes aegypti population outbreaks: basis for surveillance, alert and control system. Mem Inst Oswaldo Cruz 2008; 103:50-59.

11. Schofield C. Vector population responses to control intervention. Ann Soc Belg Med Trop 1991; 71: 201-217.

12. Natal D. Bioecologia do Aedes aegypti. São Paulo. Biológico 2002; 64:205-207.

13. Forattini OP, Brito M. Reservatórios domiciliares de água e controle do Aedes aegypti. Rev Saude Publica 2003; 37:676-677.

14. Barrera R, Amador M, Diaz A, Smith J, Munoz-Jordan JL, Rosario Y. Unusual productivity septic tanks and its implications for dengue control. Med Vet Entomol 2008; 22:62-69.

15. Ferreira AC, Neto FC. Infestação de área urbana por Aedes aegypti e relação com níveis socioeconômicos. Rev Saude Publica 2007; 41:6. 